\title{
Albin Garfield Anderson (安道善, 1882-1971): A History of Medical Missionary Work
}

\author{
Sung Ku Ahn ${ }^{1}$ and Sang Baek Koh ${ }^{2}$ \\ ${ }^{1}$ Departments of Dermatology and ${ }^{2}$ Preventive Medicine, Yonsei University Wonju College of Medicine, Wonju, Korea.
}

Albin Garfield Anderson was born on April 13, 1882 in Andover, IL, USA (Fig. 1). He was the first of two children born to a second generation Swedish immigrant. Anderson's father was a pastor at a Methodist church in Central Sweden, and worked as district superintendent in Chicago. He graduated from Lake View High School (in Chicago), Northwestern University (with a Bachelor's in Liberal Arts in 1904), and the School of Medicine at Northwestern University (1908). After completing his internship at St. Francis Hospital in Kansas, he transferred to radiology. He married Harriet Florence Peterson on November 16, 1910. After the wedding, they left the United States on December 5, 1910 and arrived in Korea on January 4, 1911. He was appointed a medical missionary for the Wonju area on March 5, 1912 at The 5th Association of the Methodist Conference in Sangdong Church, Seoul. While in Seoul, he studied Korean and worked as a faculty member at Severance Union Medical College: he was appointed director of Severance Union Medical College from 1931 to 1937. ${ }^{1}$

From April 1, 1912 to the summer of 1913, Dr. Anderson worked at the Hall Memorial Hospital in Pyeongyang as a temporary replacement for Dr. E.D. Follwell, who was on sabbatical. The Hall Memorial Union Hospital was founded jointly by Hall Memorial Hospital and Carolins A. Ladd Hospital. He founded the Swedish Methodist Hospital in Wonju on November 14, 1913. He spent his sabbatical year in 1917 in the US and returned to Wonju in the fall of 1918. Upon Dr. Follwell's resignation after 25 years of service, Bishop Welch highly recommended Dr. Anderson for his position, and thus, An-

Received: March 20, 2019

Corresponding author: Sung Ku Ahn, MD, Department of Dermatology, Yonsei University Wonju College of Medicine, 20 Ilsan-ro, Wonju 26426, Korea. Tel: 82-33-741-0621, Fax: 82-33-747-0409, E-mail: ahnsk@yonsei.ac.kr

-The authors have no potential conflicts of interest to disclose.

(C) Copyright: Yonsei University College of Medicine 2019

This is an Open Access article distributed under the terms of the Creative Commons Attribution Non-Commercial License (https://creativecommons.org/licenses/ by-nc/4.0) which permits unrestricted non-commercial use, distribution, and reproduction in any medium, provided the original work is properly cited. derson moved to Pyeongyang in August 1920. Later, the Pyeongyang Union Christian Hospital was created in 1923 through the merger of the Woman's Dispensary of Extended Grace and Hall Memorial Union Hospital. Anderson served as the director of Pyeongyang Union Christian Hospital from 1933 to 1939. Under pressure from the Japanese Empire, he returned to Chicago on December 4, 1940. In July 1941, he worked at the Methodist Hospital in Nyadiri, Southern Rhodesia (in Africa), a community healthcare center and a leprosy hospital funded by the British government. His health deteriorated due to the civil war and the local climate. He left Cape Town on December 5, 1945 and returned to the US on March 3 , 1946. He was granted a membership to the Mashonaland branch by the British Medical Association. He died of pancreatic cancer at the age of 88 . His wife passed away at the age of

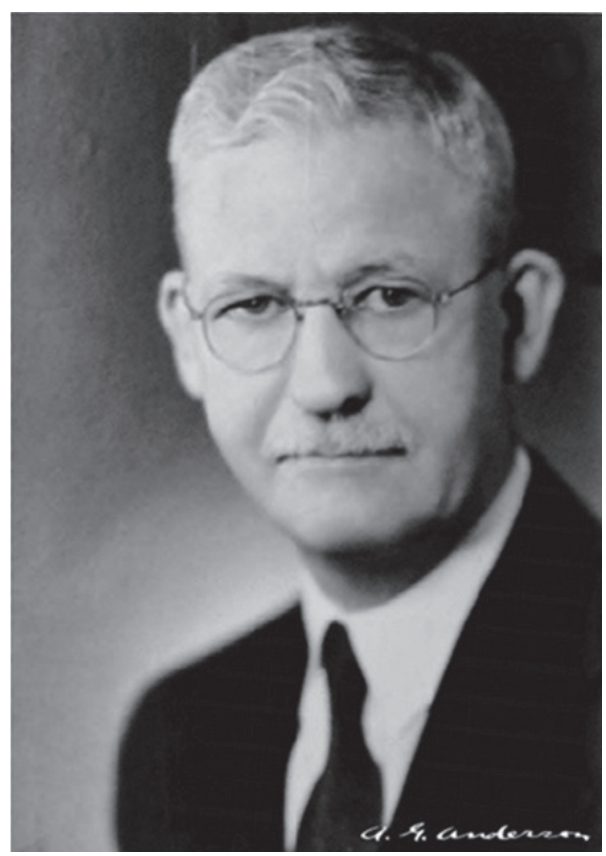

Fig. 1. A.G. Anderson (1882-1971). 
86, a few months later (she died from a myocardial infarction). The graves of the couple are located in Rose Hill, Chicago.

\section{SWEDISH METHODIST HOSPITAL}

In 1910, the headquarters of the United Methodist Church based in New York carried out the founding of a missionary hospital in Wonju in commemoration of the Quarter Centennial Jubilee of missions in Joseon, which started in $1885 .^{2}$ The hospital was named "Swedish Methodist Hospital" in honor of immigrant Swedish Methodist believers in the US (Fig. 2). Who donated construction funds totaling 5425 dollars. According to the 1918 land registry map, the hospital was located at Sangdong-ri 388 beonji, Bonbu-myeon, Wonju-gun, which is the present-day site of the emergency room of Severance Wonju Hospital.

Following three visits to Wonju (in the spring of 1911, January 1912, and May 1913), Anderson's dedication finally bore fruit. The groundbreaking ceremony for the construction of the

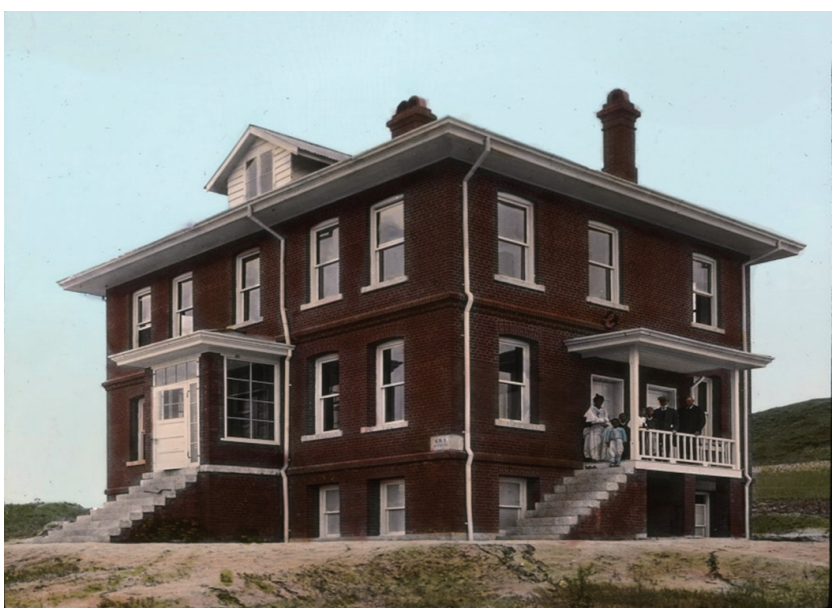

Fig. 2. Swedish Methodist Hospital (1913).
Swedish Methodist Hospital was held in the spring of 1913, followed by a cornerstone ceremony on July 15. Construction was completed in November of that same year. The work cost 5425 dollars total. The hospital was a two-story masonry building $30 \times 40$ square feet in size with a basement floor and 17 beds. The inauguration ceremony was held on April 22, 1914. ${ }^{3}$

\section{ESTABLISHMENT, MANAGEMENT, AND MEDICAL SERVICES OF SWEDISH METHODIST HOSPITAL}

Most of the funds for the construction of the hospital were provided by American Northern Methodist Church members of Swedish origin. The hospital was run with the monetary donations and material support of its donors and medical service income, in addition to aid from the missionary group. At that time, Wonju had poor transportation infrastructure with a small population. The management of this hospital was more challenging than that of Northern Methodist Hospitals based in other regions (namely Seoul, Pyeongyang, and Haeju) as there were fewer outpatients, inpatients, and operation demands at the location in Wonju. The free medical service ratio was high, and financial independence was at its lowest. Anderson, however, considered medical missions as a charity endeavor and held the view that free medical service was the essence of medical missions. Therefore, he continued to emphasize the importance of financial support from the mission headquarters. At first, there were almost no donations from the Wonju-eup town church after the hospital opened. Regular donations from the Wonju-eup town church began coming in beginning in the late 1910s to help expand free medical services and support the hospital's financial independence. According to a 1917 report, local donations from Wonju rose by $28 \%$. Its financial independence quickly jumped to $48 \%$ by 1920 (Table 1$){ }^{4}$

Table 1. Medical Services Performed at Swedish Methodist Hospital in Wonju (1913-1932)

\begin{tabular}{|c|c|c|c|c|c|c|}
\hline Period & Hospitalization & $\begin{array}{c}\text { Medical service } \\
\text { (including house calls) }\end{array}$ & Operation & $\begin{array}{c}\text { Free medical } \\
\text { service }(\%)\end{array}$ & $\begin{array}{l}\text { Medical service } \\
\text { income }\end{array}$ & $\begin{array}{l}\text { Donations from the } \\
\text { missionary society }\end{array}$ \\
\hline Sep 1913-May 1914 & 7 & 1042 & 18 & 68 & $\$ 44.61$ & - \\
\hline Jun 1914-Mar 1915 & 89 & 2157 & 29 & 70 & $\$ 231.59$ & - \\
\hline April 1915-Mar 1916 & 65 & 1958 & 34 & 75 & $\$ 200$ & - \\
\hline Jan 1916-Dec 1916 & 119 & 3055 & 84 & 52 & - & - \\
\hline Sep 1918-Sep 1919 & 221 & 4637 & 182 & - & - & - \\
\hline Oct 1919-Sep 1920 & 227 & 5604 & 163 & 65 & $¥ 5866$ & $¥ 5000$ \\
\hline Sep 1922 & 87 & 3144 & - & - & $¥ 2743$ & - \\
\hline Feb 1925-Jun 1925 & - & 2487 & 12 & - & $¥ 694.18$ & - \\
\hline 1927 & 41 & 7010 & - & - & - & - \\
\hline 1928 & 71 & 3657 & 74 & - & $¥ 2460$ & $¥ 3789$ \\
\hline Jun 1928-May 1929 & 97 & 369 & - & - & $¥ 4579$ & - \\
\hline 1931-1932 & - & 800 & - & - & - & - \\
\hline
\end{tabular}




\section{BEYOND MEDICAL MISSIONS}

Anderson preached to patients and served as the director of a Sunday school. In 1918, a co-education high school (Uijeong School) was founded, and he engaged in teaching at the institution (with Pastor Wonbaek Park as principal).

The fifth pastor of the Wonju-eup town church (evangelist Yunyeo Jo) had not yet been officially ordained at that point, so Anderson served as an interim pastor (June 1918-Sep 1920), as he was an officially ordained deacon who held annual membership. Anderson actively sought to find an eligible successor after moving to Hall Memorial Union Hospital in Pyeongyang.

He organized the area's first Western music concert in 1922. He introduced a pipe organ to the public that was donated to the Wonju-eup town church by a church in Bethany, and staged a violin performance and a vocal music concert. This was the first Western music performance ever held in the Wonju area. ${ }^{5}$

\section{MEDICAL STAFF AT THE SWEDISH METHODIST HOSPITAL}

The medical staff at the hospital comprised five westerners, including the Anderson couple, the McManis couple, and Missionary Reppert, who was in charge of anesthesiology, and five doctors who graduated from Severance Union Medical College, including Ahn Sayeong who graduated in 1917, Yun Seonuk in 1918, Kim Bongnyeol in 1922, Lee Eungye in 1927, and Lee Sangok in 1930.

In addition, although their backgrounds and education are unconfirmed, assistant Kim Yeongseok (1913), a licensed Korean doctor, and licensed nurses (1914) assisted in providing medical services (Fig. 3). ${ }^{1}$

\section{BACKGROUND FOR ANDERSON'S FAITH}

Born to a Swedish Methodist pastor, Anderson was fluent in German and Swedish and felt a sense of calling for the ministry and its mission from an early age. He was born again at the age of 12. He organized the Junior Epworth League and engaged in missionary and voluntary works. Six years later, he experienced sanctification, which is the stage that follows that of being born again.

After graduating from high school, Anderson was admitted to Northwestern University in Chicago. He graduated with a degree from the College of Liberal Arts in 1904. He served as a leader of a sectional prayer meeting, Sunday school teacher, and deacon at the church and was the Vice President of the Junior Epworth League in Chicago, as well as the President of the YMCA. He began dreaming of performing missionary

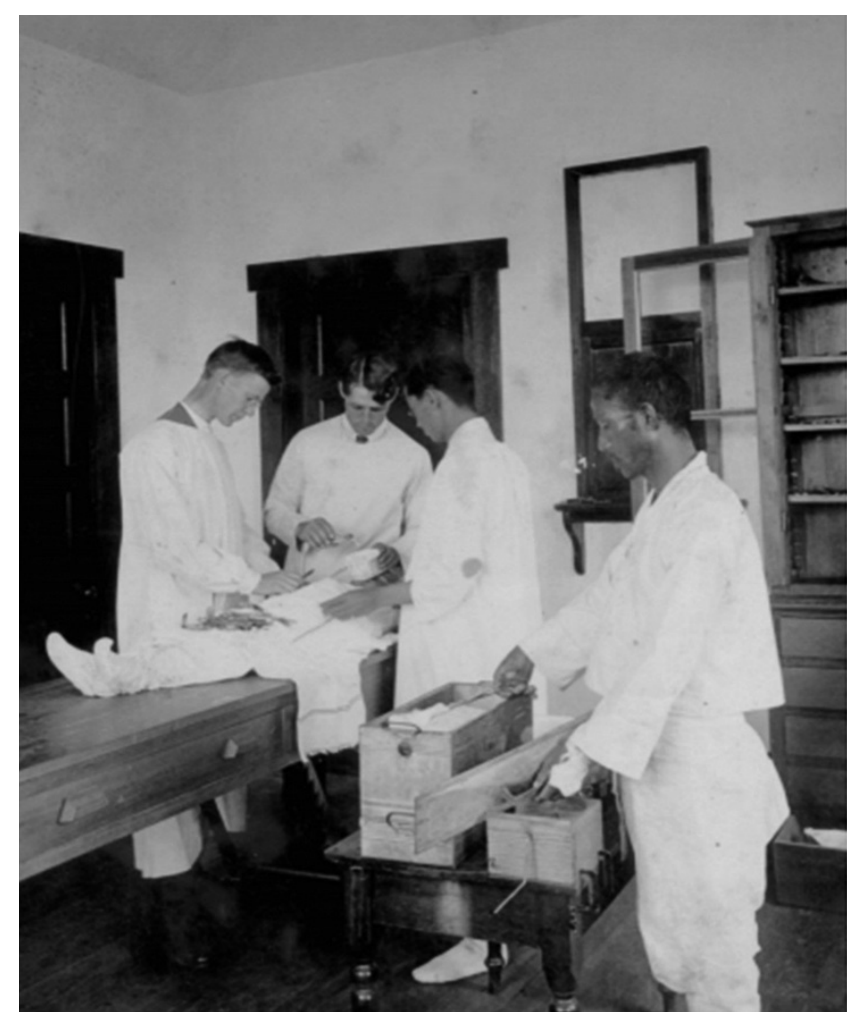

Fig. 3. Operating scene. A.G. Anderson (left), Rev. R.R. Reppert (center), S.W. Yoon (right), and a Korean assistant (1916).

work abroad during his college years. He entered the School of Medicine at Northwestern University in response to his sense of calling for missions abroad.

He wrote, "Around that time, a friend of mine introduced me to the concept of medical missions. From then on, I was fascinated by the work of medical missions abroad, which entails both spiritual and physical duties. Medical missions allow one to save people from physical pain, and at the same time, to develop close relationships with strangers. I thought that this would be the most effective way to spread the Christian faith. I attended E.J. Colton's lectures on missions at a College YMCA meeting held in Evanston, and realized the duties of my life. I was convinced that I was destined to carry out missions abroad and medical missionary endeavors. I submitted the application to participate in missions abroad during my junior year. Since that moment, I have not once regretted my decision."

He volunteered for missionary work abroad because he perceived medical missionary work, which combined the spiritual and the physical as a no-alternative calling for his mission. He graduated from the School of Medicine in June 1908. After interning at the hospital in Milwaukee, Wisconsin, Anderson was trained at St. Francis Hospital in Kansas. He submitted his missionary application to the International Missions Department of the United Methodist Church in August 1909.

One day, in July of 1910, Anderson received a letter from G.H. 
Jones in New York asking, "Are you interested in being commissioned to Korea as a missionary?" Anderson sent a reply with a response in the affirmative, "I learned about Korea for the first time at a missionary research meeting last winter. I would be honored to work in Korea. I have been longing to work as a missionary for a long time. Due to the climate, however, I hope to be commissioned somewhere that will not pose a risk to my health." G.H. Jones was appointed a missionary for Korea, and became the first missionary to visit Wonju in 1888. In 1910, the International Missions Department of the United Methodist Church based in New York was pushing the Korea Quarter-Centennial Campaign forward. Jones introduced the situation of Korean churches, and appealed to the public for its support of missionaries and missions funds. ${ }^{2}$

Four medical missionaries from the Northern Methodist Church of the US were commissioned to Korea in 1910. E.D. Follwell worked at the hospital in Pyeongyang; J.D. Vanbuskirk at the hospital in Gongju; A.H. Norton at the hospital in Haeju; and I.M. Miller at the hospital in Yeongbyeon. Anderson was given the responsibility of establishing a foundation for the missions department in Wonju and building a hospital in a very early stage of missions support in Korea. Anderson was officially appointed a missionary to Korea in September
1910. He departed from the US on December 5 and arrived on January 4, 1911. His younger sister, Naomi Anderson, was fulfilling her duties as a nurse at the East Gate Women's Hospital located in Dongdaemun, Seoul, beginning in 1910. These three members of the Anderson family initiated the first chapter of the Swedish Mission in Korea.

\section{ORCID iDs}

Sung Ku Ahn https://orcid.org/0000-0003-0978-9426

Sang Baek Koh https://orcid.org/0000-0001-5609-6521

\section{REFERENCES}

1. Ahn SK. 100 years of Wonju medical work. 1st ed. Seoul: Jinsol Pub.; 2013. p.48-9.

2. Jones GH. Christian medical work in Korea. New York: Board of Foreign Missions of the Methodist Episcopal Church; 1910.

3. Anderson AG. Dedication service of Swedish Methodist hospital, Wonju, Korea. Korea Mission Field 1914;11:331.

4. Anderson AG. Wonju medical report. Korea Ann Conf 1917;6:74-6.

5. Anderson AG. Report of Hall Memorial Union Hospital. Methodist Episcopal Church 1922;9:206-8. 